\title{
Antibacterial activity of the white lily Moringa oleifera seed extract and its use in water treatment
}

\section{Tânia Maria de Andrade ${ }^{1}$ and Krystyna Gorlach-Lira ${ }^{2}$}

${ }^{1}$ Department of Post-Graduation. Research and Extension, Science and Technology. Federal Institute of Education. Campus João Pessoa. João Pessoa-PB, Brazil (CEP 58015-435). Email: tania.andrade@ifpb.edu.br.

${ }^{2}$ Department of Molecular Biology. Laboratory of Biology of Microorganisms. Federal University of Paraíba. Cidade Universitária. João Pessoa-PB, Brazil (CEP 58051-900). Email:kglira@yahoo.com.

\begin{abstract}
White lily Moringa oleifera seed powder acts as a natural coagulant promoting the reduction of water turbidity by the coagulation and sedimentation of the suspended particles, also eliminating the microorganisms by sedimentation. The aqueous extract of $M$. oleifera presented an inhibitory capacity for the growth of Staphylococcus aureus, whereas the hydroalcoholic extract inhibited S.aureus, Salmonella typhimurium and Vibrio cholerae, using the agar diffusion test. Standard strains of Pseudomonas aeruginosa, Escherichia coli and Enterococcus faecalis were resistant to the extracts. The water treatment through the aqueous extract of M. oleifera seeds at $0.02 \%$ and $0.01 \%$ concentrations was evaluated with the water samples collected in the Sinibu River, Paraíba State, Brazil, using the jar test. The water samples analyzed in this work were characterized by low turbidity (2.8-3.0 NTU), and pH and alkalinity between $5.8-7.3$ and $10-30 \mathrm{mg} \mathrm{CaCO}_{3} / \mathrm{L}$, respectively. After water treatment with M. oleifera aqueous extract, it was observed that $\mathrm{pH}$, turbidity and alkalinity did not change significantly. Total heterotrophic bacteria counts in the crude water samples were between $1.9 \times 10^{5} \mathrm{UFC} / 100 \mathrm{~mL}$ and $1.1 \mathrm{x}$ $10^{6} \mathrm{CFU} / 100 \mathrm{~mL}$, while the number of fecal coliforms was between $2.3 \times 10^{2} \mathrm{NMP} / 100 \mathrm{~mL}$ and $2.4 \times 10^{3} \mathrm{NMP} / 100 \mathrm{~mL}$. The counts of total bacteria and fecal coliforms in the water samples treated with aqueous white lily extract at both concentrations tested $(0.02 \%$ and $0.01 \%)$ during the 1.5 -hour period did not differ significantly when compared to the untreated water. The results obtained in this work indicate that low turbidity of water influenced the efficacy of $M$. oleifera extract in the removal of bacteria in the treated water, since the level of coagulation depends on water turbidity.
\end{abstract}

Keywords: Moringa oleifera; Antibacterial activity; Bacteria; Fecal coliforms.
Received

September 24, 2018

Accepted

December 28, 2018

Released

December 31, 2018

Full Text Article

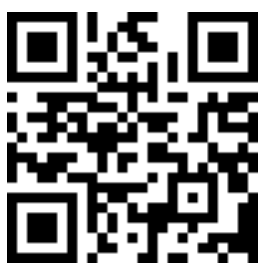

ORCID

(1) 0000-0002-1536-9009

Tânia Maria de Andrade

(D) 0000-0002-7892-2705 Krystyna Gorlach-Lira 


\section{Introduction}

Coagulation and flocculation followed by sedimentation, filtration, and chlorine-based disinfection are used as steps in a conventional treatment prior to the distribution of treated water to consumers (Edzwald et al., 1989). Aluminum salts and iron salts are the most widely used coagulants in the world. The cost and adverse environmental effects of these compounds increased the interest in using organic coagulants or flocculants from plant material, such as Moringa oleifera seeds, for water treatment (Jahn et al., 1986; Olsen, 1987; Amagloh and Benang, 2009; Arantes et al., 2012).

Moringa is a multipurpose tree that serves as a food plant (leaves, green pods, flowers and roasted seeds), forage (leaves, pods and seeds), honeybee (flowers), medicinal (all parts of the plant), and fuel (wood and oil) (Jahn et al., 1986; Folkard et al., 1995; Moyo et al., 2011; Keatinge et al., 2015; Gopalakrishnan et al., 2016; Taher et al., 2017). The coagulants of $M$. oleifera were recommended for treatment of water in Africa and Asia in order to offer better water quality and, consequently, to guarantee more health to the population (Okuda et al., 2001; Amagloh and Benang, 2009; Kasolo et al., 2010). Moringa seed powder as a natural coagulant promotes the reduction of water turbidity by the coagulation and sedimentation of the suspended particles, as well as the elimination of pathogenic microorganisms by sedimentation, since most of the microbes are bound to the suspended particles. $M$. oleifera seeds contain significant amounts of positively charged soluble proteins. When the seed powder is added to the cloudy water, the proteins release positive charges by attracting the negatively charged particles such as clay, bacteria, and other toxic particles present in water forming flakes and aggregating the particles present in the water (Santos et al., 2009; Ferreira et al. 2009).

A number of authors report the antibacterial activity of the aqueous and ethanolic extracts of $M$. oleifera seeds (Gerdes, 1996; Rangsamy et al., 2007, Vieira et al., 2010). Rangasamy et al. (2007) observed that the methanolic extract inhibited the growth of Salmonella enteritidis, Enterobacter cloacae and Bacillus subtilis. In relation to the removal of bacteria, reductions in the order of $90-99 \%$ have been reported in literature (Gerdes, 1996).

The presence of pathogenic
bacteria in water for human consumption necessarily implies the disqualification of this water and high potential for compromising the human health. To improve the conditions of water intended for human consumption as well as used in handling for fruit washing and disinfection, it is necessary to use alternative treatments in order to minimize or eliminate the impacts that the pathogenic bacteria coming from water transport bring to the communities, particularly in areas that do not have the conventional water treatment plants.

The seeds of M. oleifera used in water clarification are indicated for use in low income communities in the interior of Brazil, where it is cultivated for this application. In the indigenous community of Baia da Traicao, Paraiba state, Brazil, the $M$. oleifera was introduced to the community of Lagoa do Mato in 1998 through a partnership project between the Federal Center of Technological Education of Paraíba (CEFET-PB) and the National Indigenous Foundation, Regional Administration of Paraíba (FUNAI-AR/PB). The insertion of $M$. oleifera in the communities was carried out by institutions through partnership projects, in the perspective to offer these communities an alternative domestic water treatment.

The aim of this work was to evaluate the action of the aqueous and 
hydroalcoholic extract of $M$. oleifera seeds on human pathogenic bacteria, as well as its effect on some physicochemical and microbiological parameters in water from the Sinibu River, Paraiba state, Brazil, used for human consumption in rural communities.

\section{Methods}

\section{Analysis of the antibacterial activity of M. oleifera}

For the preparation of the aqueous and hydroalcoholic extracts the scarified seeds of the $M$. oleifera tree were used. Figure 1 shows the aspects of the plant used in this study.

The aqueous extract of $M$. oleifera (2\%) was prepared according to Gerdes (1996) using $2 \mathrm{~g}$ of seeds and homogenized in $100 \mathrm{~mL}$ of sterile distilled water using a sterile laboratory blender. The obtained extract was filtered in a sterile cotton cloth and analyzed up to $24 \mathrm{~h}$.

The hydroalcoholic extract (50\%) was prepared by homogenizing $100 \mathrm{~g}$ of scarified seeds in $200 \mathrm{~mL}$ of $70 \%$ alcohol. The obtained homogenate was stored in a amber flask for eight days in a dark environment, stirring it daily with a stirring rod. After this period, the extract was filtered and stored in a amber flask.

The antibacterial activity of M. oleifera aqueous and hydroalcoholic extract was tested by the agar diffusion method using the following standard strains of bacteria: Staphylococcus aureus, Salmonella typhimurium, Vibrio cholerae, Escherichia coli, Enterococcus faecalis and Pseudomonas aeruginosa. The bacterial strains were obtained from the collection of cultures from the Adolfo Lutz Institute in São Paulo-SP.

The standard strains were inoculated into $5 \mathrm{~mL}$ Brain Heart Infusion medium (Oxoid) and incubated at $37{ }^{\circ} \mathrm{C}$ for $24 \mathrm{~h}$. Bacterial cultures were diluted to obtain at a suspension of 0.5 McFarland standard and then the $1 \mathrm{~mL}$ aliquots were spread on the Mueller Hinton Agar medium. The wells were made in the inoculated plates and $50 \mu \mathrm{L}$ of the following concentrations of the aqueous extract were placed into the wells: $2.0,1.0,0.5,0.25,0.125,0.015$, 0.06 and 0.03 and $0.015 \%$. Plates were incubated at $37^{\circ} \mathrm{C}$ for $48 \mathrm{~h}$. After incubation, the inhibition halos of bacterial cultures were measured and expressed in $\mathrm{mm}$.

\section{Water treatment with aqueous extract of $M$. oleifera seeds}

The effect of $M$. oleifera aqueous extract on some physicochemical and bacteriological parameters of water was analyzed using the water samples that were collected in the Sinibu River, the main river of the Potiguara in Paraíba State, Brazil, in the Village of Traiçoeira, Baia da Traição (Figure 1). In the indigenous communities of the Baía da Traição Municipality, the white lily (Figure 2) was introduced in 1998 through a partnership project between the Federal Center of Technological Education of Paraíba (CEFET-PB) and the National Indigenous Foundation, Regional Administration of Paraíba (FUNAI-AR/PB)

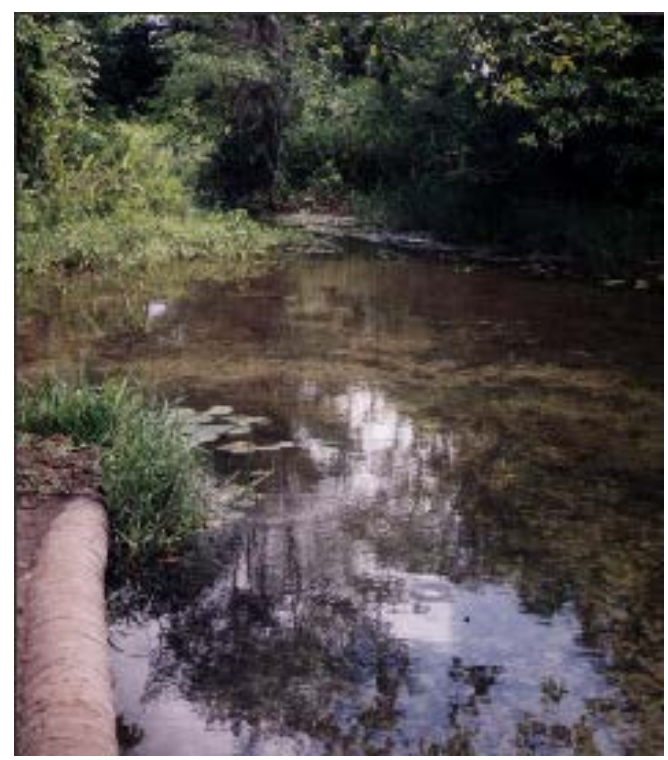

Figure 1. The source of Sinibu River at Traçoeira Village, Baía da Traição, Paraíba State, Brazil.

In order to perform the physical and chemical tests, the water was 
collected in a $10 \mathrm{~L}$ flask and the water samples for microbiological evaluation were collected in sterile $1 \mathrm{~L}$ flasks and transported in isothermal boxes containing ice until processing performed up to $24 \mathrm{~h}$ after collection.
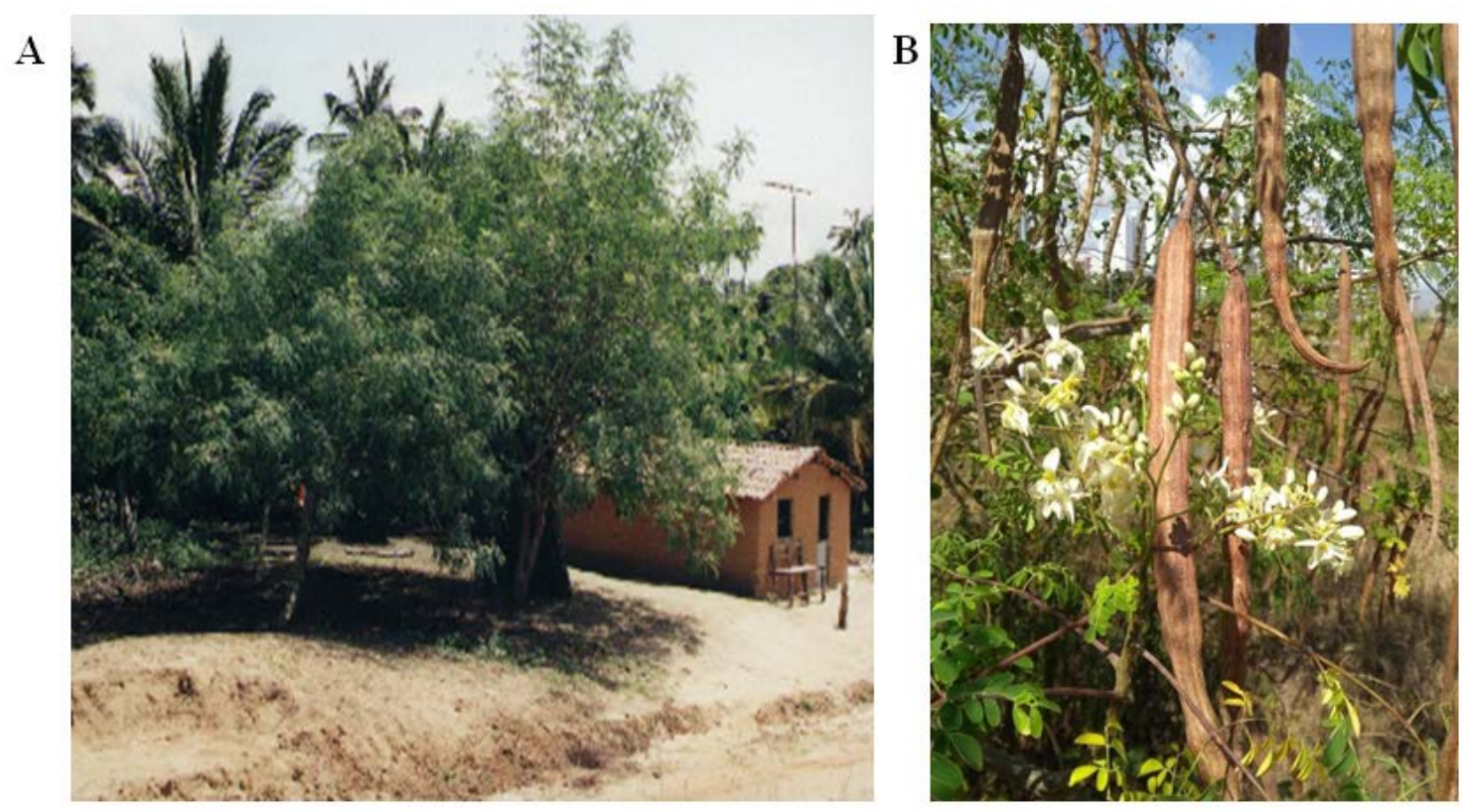

Figure 2. Moringa oleifera cultivated at the Indigen Community at Baía da Traição Municipality, Paraíba State, Brazil (A), flowers and pods (B).

The water treatment process with water extract of $M$. oleifera was carried out using jar test (Kawamura, 1991) as follows: to $1000 \mathrm{~mL}$ of water was added $10 \mathrm{~mL}$ (final concentration $0.02 \%$ ) or $5 \mathrm{~mL}$ (final concentration $0.01 \%$ ) of extract. A jar without addition of extract served as the control. The jars were stirred for one minute at $130 \mathrm{rpm}$ and then for 5 minutes at $20 \mathrm{rpm}$, covered and left to rest for the withdrawal of samples at time 0 (control) and $1.5 \mathrm{~h}$ for analysis of bacterial counts in the water column. The following parameters of the crude and treated water with extract of $M$. oleifera $(0.02 \%$ and $0.01 \%)$ for $1.5 \mathrm{~h}$ were determined: $\mathrm{pH}$, turbidity and total alkalinity. Determination of $\mathrm{pH}$ and turbidity values was performed according to the methodology of the Technical Manual of Water Analysis for Human Consumption (FNS, 1999). Total alkalinity was determined by the titration method using methylorange and $0.02 \mathrm{~N} \mathrm{H}_{2} \mathrm{SO}_{4}$ (APHA, 1998).
Bacteriological analyzes of crude water and treated water samples with extract of M. oleifera $(0.02 \%$ and $0.01 \%)$ for $1.5 \mathrm{~h}$ consisted of quantification of total mesophilic bacteria and fecal coliforms. The counts of total mesophilic bacteria were performed on Plate Count Agar medium (OXOID). Decimal dilutions of samples were performed in $0.85 \%$ saline solution, which were plated and incubated at $30{ }^{\circ} \mathrm{C}$ for $48 \mathrm{~h}$. The counts were expressed in CFU/100 mL of water. The quantification of fecal coliforms in water was done through the technique of Multiple Tubes with a series of five tubes with 95\% (Speck, 1984).

In order to analyze the total and fecal coliform density data, one-way ANOVA and Tukey's Test were used, considering a significance level of $5 \%$.

\section{Results and discussion}

Brazilian Northeast, especially the Semi-Arid Region, is experiencing a scarcity of water combined with 
microbial contamination as a result of inadequate land and water use. Providing an economical and feasible alternative for the treatment of drinking water in rural areas in need has led to the recommendation of the use of $M$. oleifera seeds. Due to the efficiency in the reduction of muddy water turbidity and the ease of cultivation of $M$. oleifera in regions of low precipitation, the use of seeds of this plant has been stimulated by governmental and non-governmental organizations in the rural areas of Brazilian Northeast.

Regarding to the analysis of antibacterial activity of the aqueous extract of $M$. oleifera seeds, in this work was observed that among the pathogenic bacteria tested only S. aureus was inhibited by aqueous extract of M. oleifera seeds, with minimum inhibitory concentration of $0.25 \%$ of the extract (Table 1). The hydroalcoholic extract was more effective inhibiting the growth of three bacterial species of the six analyzed. S. aureus, $S$. typhimurium and V.cholerae were sensitive to this extract (Table 2). The strains of P. aeruginosa, E. coli and E. faecalis were resistant to the aqueous and hydroalcoholic extract.

Sousa et al. (2014) analyzing the antimicrobial activity of the crude aqueous extract against $E$. coli, $S$. aureus and $P$. aeruginosa observed that only $S$. aureus showed sensitivity to the extract, corroborating with the data obtained in this work. Vieira et al. (2010) also observed inhibition of $S$. aureus by aqueous and ethanolic extract of Moringa seeds.

Table 1. Zone of inhibition (mm) of pathogenic bacteria by Moringa oleifera aqueous seed extract.

\begin{tabular}{lcccccccc}
\hline \multirow{2}{*}{ Strain } & \multicolumn{7}{c}{ Extract concentration (\%) } \\
\cline { 2 - 9 } & $\mathbf{2 . 0}$ & $\mathbf{1 . 0}$ & $\mathbf{0 . 5}$ & $\mathbf{0 . 2 5}$ & $\mathbf{0 . 1 2 5}$ & $\mathbf{0 . 0 6 3}$ & $\mathbf{0 . 0 3}$ & $\mathbf{0 . 0 1 5}$ \\
\hline S. aureus & 20 & 16 & 15 & 14 & 0 & 0 & 0 & 0 \\
S. typhimurium & 0 & 0 & 0 & 0 & 0 & 0 & 0 & 0 \\
V. cholerae & 0 & 0 & 0 & 0 & 0 & 0 & 0 & 0 \\
P. aeruginosa & 0 & 0 & 0 & 0 & 0 & 0 & 0 & 0 \\
E. coli & 0 & 0 & 0 & 0 & 0 & 0 & 0 & 0 \\
E. faecalis & 0 & 0 & 0 & 0 & 0 & 0 & 0 & 0 \\
\hline
\end{tabular}

Table 2. Zone of inhibition ( $\mathrm{mm}$ ) of pathogenic bacteria by Moringa oleifera hydroalcoholic seed extract.

\begin{tabular}{lcccccccc}
\hline \multirow{2}{*}{ Strain } & \multicolumn{7}{c}{ Extract concentration (\%) } \\
\cline { 2 - 9 } & $\mathbf{5 0}$ & $\mathbf{2 5}$ & $\mathbf{1 2 . 5}$ & $\mathbf{6 . 2 5}$ & $\mathbf{3 . 1 2 5}$ & $\mathbf{1 . 5 6}$ & $\mathbf{0 . 7 8}$ & $\mathbf{0 . 3 9}$ \\
\hline S. aureus & 30 & 20 & 15 & 12 & 12 & 12 & 10 & 10 \\
S. typhimurium & 20 & 15 & 15 & 15 & 20 & 0 & 0 & 0 \\
V. cholerae & 25 & 20 & 20 & 20 & 16 & 14 & 12 & 14 \\
$P$. aeruginosa & 0 & 0 & 0 & 0 & 0 & 0 & 0 & 0 \\
E. coli & 0 & 0 & 0 & 0 & 0 & 0 & 0 & 0 \\
E. faecalis & 0 & 0 & 0 & 0 & 0 & 0 & 0 & 0 \\
\hline
\end{tabular}

Rockwood et al. (2013) observed that $M$. oleifera seed extract was more effective against Gram positive than Gram negative bacteria. The authors described that four species of the 14 analyzed were sensitive to the extract (B. sphaericus, M. smegmatis, S. aureus and $A$. faecalis).

Ferreira et al. (2009) described water-soluble lectins in M. oleifera seeds 
which showed coagulant activity in turbid waters and reduced the growth of $S$. aureus and E. coli. Moura et al. (2015), analyzing the protein fractions obtained from leaf powder of M. oleifera, observed antibacterial activity against $S$. aureus, E. coli, E. faecalis and S. enteritidis.

Table 3 shows some physical, chemical and microbiological parameters of the water of the Sinibu River, Baía da Traição Municipality (Paraíba), submitted to treatment with the aqueous extract of M. oleifera.

The water samples analyzed were characterized by low turbidity that showed variations between 1.8 and 3 NTU (Table 2). The pH values ranged from 5.8 to 7.4 and alkalinity from 10 to $30 \mathrm{mg} \mathrm{CaCO}_{3} / \mathrm{L}$ (Table 3).

After treatment of water samples with the $M$. oleifera aqueous extract, we observed that $\mathrm{pH}$, turbidity and alkalinity did not change significantly (Table 3). The turbidity was not altered in samples $\mathrm{A}$ and $\mathrm{C}$ after treatment with extract, however, sample B showed an increase in turbidity. The crude water of sample B was the least turbid of the analyzed samples (1.8 NTU), while the other samples showed higher turbidity.

Table 3. Physico-chemical parameters and numbers of total bacteria and fecal coliforms in untreated water and water with addition of $0.01 \%$ and $0.02 \%$ of Moringa oleifera aqueous seed extract after $1.5 \mathrm{~h}$ treatment.

\begin{tabular}{|c|c|c|c|}
\hline \multirow{2}{*}{ Sample } & \multirow{2}{*}{ Untreated water } & \multicolumn{2}{|c|}{ Extract concentration (\%) } \\
\hline & & 0.01 & 0.02 \\
\hline \multicolumn{4}{|c|}{ Turbidity (NTU) } \\
\hline $\mathrm{A}$ & 3.0 & 3.2 & 3.2 \\
\hline B & 1.8 & 3.1 & 5.0 \\
\hline $\mathrm{C}$ & 2.8 & 2.8 & 2.8 \\
\hline \multicolumn{4}{|l|}{$\mathrm{pH}$} \\
\hline A & 7.4 & 7.3 & 7.3 \\
\hline B & 5.8 & 5.8 & 5.8 \\
\hline $\mathrm{C}$ & 6.2 & 6.4 & 6.4 \\
\hline \multicolumn{4}{|c|}{ Alcalinity $\left(\mathrm{mg}\right.$ of $\mathrm{CaCO}_{3} / \mathrm{L}$ ) } \\
\hline $\mathrm{A}$ & 30 & 32 & 31 \\
\hline B & 11 & 11 & 11 \\
\hline $\mathrm{C}$ & 10 & 13 & 14 \\
\hline \multicolumn{4}{|c|}{ Total bacteria (CFU/100 mL) } \\
\hline A & $1.1 \times 10^{6}$ & $7.1 \times 10^{6}$ & $7.1 \times 10^{6}$ \\
\hline B & $1.8 \times 10^{5}$ & $9.1 \times 10^{6}$ & $1.7 \times 10^{6}$ \\
\hline $\mathrm{C}$ & $1.9 \times 10^{5}$ & $3.1 \times 10^{6}$ & $2.5 \times 10^{6}$ \\
\hline \multicolumn{4}{|c|}{ Fecal coliforms (MPN/ 100mL) } \\
\hline A & $2.3 \times 10^{2}$ & $2.3 \times 10^{2}$ & $2.1 \times 10^{3}$ \\
\hline B & $2.4 \times 10^{3}$ & $1.5 \times 10^{3}$ & $4.6 \times 10^{3}$ \\
\hline $\mathrm{C}$ & $2.3 \times 10^{2}$ & $4.0 \times 10^{2}$ & $4.0 \times 10^{2}$ \\
\hline
\end{tabular}

The $\mathrm{pH}$ values remained constant in sample B (5.8) and with little change in samples A (7.3-7.4) and C (6.2-6.4). Regarding alkalinity, there was a slight increase of this parameter in sample $A$ in relation to crude water (Table 3 ).

Pozzopon and Kempka (2015) observed a slight increase in alkalinity and $\mathrm{pH}$ in water treated with M. oleifera extract, while Silva et al. (2007) did not show a significant variation of alkalinity in the treatment of domestic sewage.

Ndabigengesere and Narasiah (1998) showed that the extract of M. oleifera seeds does not significantly affect the $\mathrm{pH}$, conductivity, alkalinity and concentration of cations and anions of 
water, except when orthophosphates and nitrates are added.

The counts of total mesophilic bacteria in the crude water samples varied from $1.1 \times 10^{6}$ to $1.9 \times 10^{6}$ $\mathrm{CFU} / 100 \mathrm{~mL}$ and fecal coliforms from 2.3 $\mathrm{x} 10^{2}$ to $2.4 \mathrm{x} 10^{3} \mathrm{NMP} / 100 \mathrm{~mL}$ (Table 3 ). The bacterial counts in the samples treated with the extract for $1.5 \mathrm{~h}$ did not differ significantly from the values observed in untreated water (Table 3).

The evaluation of the number of mesophilic bacteria serves to reflect the favorable conditions in which such microorganisms can multiply, noting that the pathogenic bacteria that may contaminate water, are usually mesophilic. The recommended treatment time for water consumption is $1.5 \mathrm{~h}$, however, there was no significant decrease in the number of bacteria after this period.

In relation to the number of fecal coliforms after $1.5 \mathrm{~h}$ of treatment, similar values were observed in the control water and treated water with $0.01 \%$ and $0.02 \%$ of the extracts (Table 3 ).

According to Olsen (1987), using a suitable seed dosage, the number of fecal coliforms in turbid waters can be reduced by $98 \%$ to $100 \%$. Pinto and Hermes (2006) observed that the greater the turbidity of raw water, the faster the efficiency of the M. oleifera seeds in the coagulation/flocculation process, and the more turbid the water, the more seeds is needed. Among the water treatment systems using M. oleifera seeds tested by these authors, the best results in the reduction of total and fecal coliforms were the system using seeds of $M$. oleifera followed by the slow sand filtering, however, in the majority of the tests the coliforms were not $100 \%$ reduced.

In the non-turbid waters treated with aqueous extract of $M$. oleifera seeds analyzed in this work there was no significant reduction of bacteria. The efficacy of the $M$. oleifera extract in the removal of bacteria in the water analyzed in this work may be associated with low turbidity of water. According to Schwarz (2000), the time required for coagulation depends on the turbidity level of the water. Most of the cited authors analyzed very turbid water (120-298 NTU), while water analyzed in the present study presented turbidity around 1.8-3.0 NTU.

\section{Conclusions}

The antibacterial effect of M. oleifera seeds extract was observed in vitro against Staphylococcus aureus (aqueous extract), and S. aureus, Salmonella typhimurium and Vibrio cholerae (hydroalcoholic extract). The treatment of low turbidity water by the aqueous extract of $M$. oleifera seeds did not affect significantly physicochemical characteristics of water samples. The low efficacy of the removal of bacteria from water characterized by low turbidity by the $M$. oleifera seeds extract was shown, since the numbers of total bacteria and fecal coliforms did not decreased significantly after the treatment.

\section{Conflicts of interest}

Authors declare that they have no conflict of interests.

\section{References}

Amagloh, F. K.; Benang, A. Effectiveness of Moringa oleifera seed as coagulant for water purification. African Journal of Agriculture Research, v. 4, n. 1, p. 119-123, 2009.

APHA - American Public Health Association. Standard methods for the examination of water and wastewater. 20. ed. Washington, D.C.: APHA, AWWA, WEF, 1998.

Arantes, C. C.; Ribeiro, T. A.; Paterniani, J. E. S. Processamento de sementes de Moringa oleifera utilizando-se diferentes equipamentos para obtenção de solução coagulante. Revista Brasileira de Engenharia Agrícola e Ambiental, v. 16, no. 6, p. 661-666, 2012. https://doi.org/ 10.1590/S1415-43662012000600011

Edzwald, J. K.; Dempsey, B. A.; Amirtharajah, A.; Dentel, S. K.; Lawler, D. F.; Letterman, R. D.; O'Melia, C. R.; Randtke, S. J.; Wiesner, M. R. Coagulation as an integrated water treatment process. Journal AWWA, v. 81, p. 72-78, $1989 . \quad$ https://doi.org/10.1002/j.15518833.1989.tb03292.x 
Ferreira, R. S.; Napoleão, T. H.; Santos, A.F.; Sá, R.A.; Carneiro-da-Cunha, M. G.; Morais, M. M.; Silva-Lucca, R. A.; Oliva, M. L.; Coelho, L. C.; Paiva, P. M. Coagulant and antibacterial activities of the water-soluble seed lectin from Moringa oleifera. Letter Applied Microbiology, v. 53, no. 2, p. 186-192, 2011. https://doi.org/10.1111/j.1472-765X.2011. 03089.x

FNS - Fundação Nacional de Saúde. Manual técnico de análise de água para consumo humano. Brasília, DF: Ministério da Saúde, Fundação Nacional de Saúde, 1999.

Folkard, G. K.; Sutherland, J.; Al-Khalili. Natural coagulants: A sustainable approach. Proceedings of the 21st WEDC Conference, Kampala, Uganda, 4-8 September, 1995. p. 263-265. Available from: <https://wedcknowledge.lboro.ac.uk/resources/conference /21/Folkard.pdf>. Accessed on: Feb. 05, 2017.

Gerdes, G. 0 uso das sementes da árvore moringa para o tratamento de água turva. Fortaleza: ESPLAR - Centro de Pesquisa e Assessoria, 1996.

Gopalakrishnan, L.; Doriya, K.; Kumar, D. S. Moringa oleifera: A review on nutritive importance and its medicinal application. Food Science and Human Wellness, v. 5, p. 49-56, 2016. https://doi.org/10.1016/j.fshw. 2016.04.001

Jahn, S. A. A.; Musnad, H. A.; Burgstaller, H. The tree that purifies water: Cultivating multipurpose Moringaceae in the Sudan. Unasylva, v. 38, p. 23-28, 1986. Available from: <http://www.fao.org/docrep/r7750e/ r7750e04.htm>. Accessed on: Feb. 05, 2017.

Keatinge, J. D. H.; Ebert, A. W.; Hughes, J. D. A.; Yang, R.-Y.; Curaba, J. Seeking to attain the UN's Sustainable Development Goal 2 worldwide: The important role of Moringa oleifera. Acta Horticulture, v. 1158, p. 1-10, 2015. https://doi.org/10.17660/ActaHortic. 2017.1158.1

Kawamura, S. Effectiveness of natural polyelectrolyts in water treatment. Journal AWWA, v. 83, p. 88-91, 1991. https://doi.org/10.1002/j.1551-8833.1991. tb07236.x

Kasolo, J. N.; Bimenya, G. S.; Ojok, L.; Ochieng, J.; Ogwal-Okeng, J. W. Phytochemicals and uses of Moringa oleifera leaves in Ugandan rural communities. Journal of Medicinal Plants Research, v. 4, p. 753-757, 2010. https://doi.org/10.5897/JMPR10.492

Moura, C. M.; Mendonça, R. A.; Paiva, P. M. G.; Coelho, L. C. B. B. Atividade antibacteriana de preparações de folhas de Moringa oleifera contendo inibidor de tripsina. Arrudea, v. 1, no. 1 , p. 12-18, 2015. https://doi.org/ 10.2446/arrudea.v1i1.3

Moyo, B.; Masika, P. J.; Hugo, A.; Muchenje, V. Nutritional characterization of Moringa (Moringa oleifera Lam.) leaves. African Journal of Biotechnology, v. 10, p. 1292512933, 2011. https://doi.org/10.5897/ AJB10.1599

Ndabigengesere, A.; Narasiah, K. S. Quality of water treated by coagulation using Moringa oleifera seeds. Water Research, v. 32, p. 781791, 1998. https://doi.org/10.1016/S00431354(97)00295-9

Okuda, T.; Baes, U. B.; Nishijima, W.; Okada, $\mathrm{M}$. Isolation and characterization of coagulant extracted from Moringa oleifera seed by salt solution. Water Research, v. 35, p. 405-410, 2001. https://doi.org/10.1016/S00431354(00)00290-6

Olsen, A. Low technology water purification by bentonite clay and Moringa oleifera seed flocculation as performed in Sudanese villages: Effects on Schistosoma mansoni cercariae. Water Research, v. 21, p. 517-522, 1987. https://doi.org/10.1016/00431354(87)90059-5

Pinto, N. O.; Hermes, L. C. Sistema simplificado para a melhoria da qualidade da água consumida por comunidades rurais do semi-árido do Brasil. Anais do 5ํㅗ Simpósio Brasileiro de Captação e Manejo de Água de Chuva, Petrolina-PE, 2005. Available from: <https://ainfo.cnptia.embrapa.br/digital/bit stream/CNPMA/7457/1/documentos_53.pdf >. Accessed on: Feb. 05, 2017.

Pozzopon, L.; Kempka, A. P. Sementes de Moringa oleifera na clarificação de efluente de indústria de ingredientes para alimentação animal: comparação com o coagulante convencional e estudo das condições operacionais. Engevista, v. 17, no. 2, p. 196-206, 2015. Available from: <http://www.editorarealize.com.br/revistas /conapesc/trabalhos/TRABALHO_EV058_MD 4_SA81_ID682_16052016223352.pdf>.

Accessed on: 05 Feb. 2017.

Rangasamy, 0.; Raoelison, G.; Rakotoniriana, F. E.; Cheuk, K.; Urverg-Ratsimamanga, S.; Quetin-Leclercq, J.; Gurib-Fakim, A.; Subratty, A. H. Screening for anti-infective properties of several medicinal plants of the Mauritians flora. Journal of Ethnopharmacology, v. 109 , p. 331-337, 2007. https://doi.org/ 10.1016/j.jep.2006.08.002 
Rockwood, J. L.; Anderson, B. G.; Casamatta, D. A. Potential uses of Moringa oleifera and an examination of antibiotic efficacy conferred by $M$. oleifera seed and leaf extracts using crude extraction techniques available to underserved indigenous populations. International Journal of Phytotherapy Research, v. 3, p. 61-71, 2013.

Santos, A. F. S.; Argolo, A. C. C.; Coelho, L. C. B. B.; Paiva, P. M. G. Detection of water soluble lectin and antioxidant component from Moringa oleifera seeds. Water Research, v. 39, p. 975-980, 2005. https://doi.org/ 10.1016/j.watres.2004.12.016

Schwartz, D. Water clarification using Moringa oleifera. Eschborn: Gate Information Service, 2000. Available from: <http://www.gtz.de/gate/gateid.afp>.

Acessed on: Feb. 05, 2017.

Silva, M. E. R.; Aquino, M. D.; Santos, A. B. Póstratamento de efluentes provenientes de reatores anaeróbios tratando esgotos sanitários por coagulantes naturais e não naturais. Revista Tecnologia, v. 28, no. 2, p.178-190, 2007. Available from: <http://periodicos.unifor.br/tec/article/vie w/55/>. Accessed on: Feb. 05, 2017.

Souza, J. P. G.; Rosa, C. E.; Assunção, D. E. S. Atividade antimicrobiana do extrato bruto da Moringa oleifera Lam em função do binômio tempo/temperatura. Anais do XII Congresso Latino Americano de Microbiologia e Higiene de Alimentos, v. 1, p. 117-118, 2014. https://doi.org/10.5151/foodsci-microal328
Speck, M. L. Compendium of methods for the microbiological examination of food. New York: American Public Health Association, 1984.

Taher, M. A.; Nyeem, M. A. B.; Ahammed, M. M.; Hossain, M. M.; Islam, M. N. Moringa oleifera (shajna): The wonderful indigenous medicinal plant. Asian Journal of Medical and Biological Research, v. 3, p. 20-30, 2017. http://doi.org/10.3329/ajmbr.v3i1. 32032

Vieira, G. H. F.; Mourão, J. A.; Angelo, A. M., Costa, R. A.; Vieira, S. D. F. Antibacterial effect (in vitro) of Moringa oleifera and Annona muricata against Gram positive and Gram negative bacteria. Revista do Instituto de Medicina Tropical de São Paulo, v. 52, no. 3, p. 129-132, 2010. https://doi.org/ 10.1590/S0036-46652010000300003 